\title{
Spontaneous pneumothorax in a patient with pneumocystis pneumonia
}

\author{
Richard GR Lloyd, ${ }^{1}$ Frances Aitchison, ${ }^{2}$ Guy Hagan ${ }^{1}$
}

${ }^{1}$ Department of Respiratory Medicine, Sandwell and West Birmingham Hospitals NHS Trust, Birmingham, UK ${ }^{2}$ Department of Radiology, Sandwell and West Birmingham Hospitals NHS Trust, Birmingham, UK

\section{Correspondence to} Dr Richard GR Lloyd, richard_lloyd@nhs.net

Accepted 19 February 2017
CrossMark

\section{To cite: Lloyd RGR,} Aitchison F, Hagan G. BMJ Case Rep Published online: [please include Day Month Year] doi:10.1136/bcr-2017219754

\section{DESCRIPTION}

A woman aged 35 years presented with a 6-week history of worsening shortness of breath. She previously had TB in her early 20s, but had no other medical history of note. She had been referred several months earlier due to an abnormal chest $\mathrm{X}$-ray suggestive of an interstitial lung disease but had not attended. She has previously been an intravenous drug user.

The patient had intermittent fever and rigors, night sweats, diaphoresis and diarrhoea. At admission, she was cachectic and tachypnoeic, with clubbing and cervical lymphadenopathy.

An HIV test was found to be positive, with a CD4 count of 101 cells $/ \mathrm{mm}^{3}$. The initial chest radiograph showed diffuse alveolar shadowing. CT imaging and bronchoscopy confirmed pneumocystis pneumonia. Cystic lesions in the lung, consistent with pneumatoceles, were visible on CT thorax (figure 1). She was treated with cotrimoxazole and prednisolone.

However, she deteriorated acutely and was in respiratory distress. Repeat chest X-ray showed a spontaneous right-sided pneumothorax, which was treated with therapeutic aspiration (figure 2).

She recovered well from this during the admission, and was started on antiretroviral medication. Unfortunately, she has not attended follow-up appointments.

Pneumocystis infection can present with spontaneous pneumothorax, in $2-6 \%$ of cases. ${ }^{1}$ It is primarily a disease of the immunocompromised. The aetiology is most likely due to severe necrotising

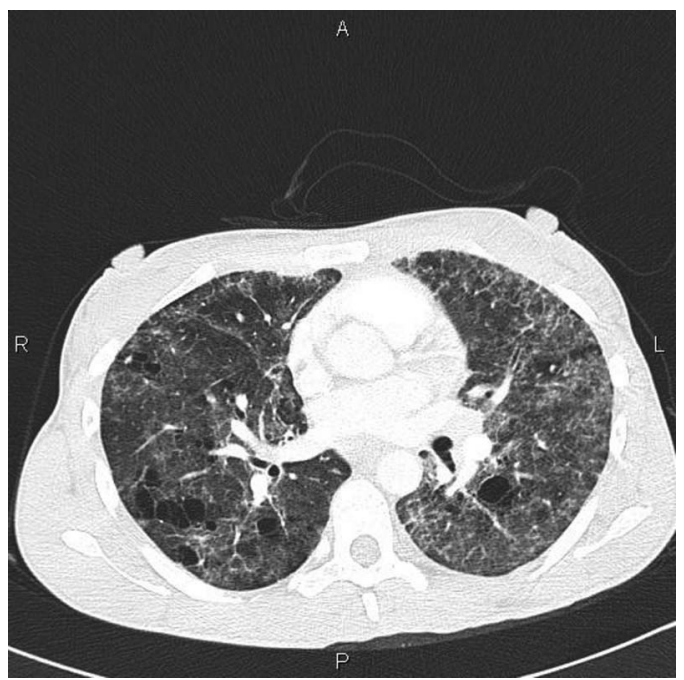

Figure 1 CT showing pneumatocoeles prepneumothorax.

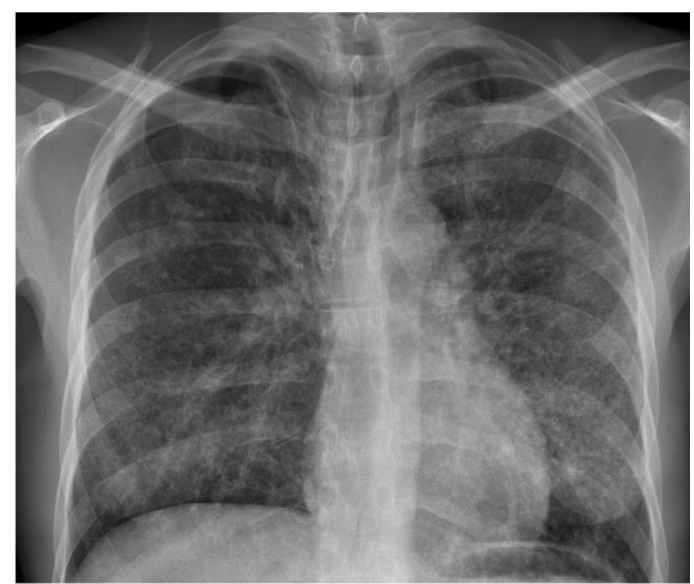

Figure 2 Pneumothorax on chest radiograph.

alveolitis, leading to replacement of the lung parenchyma by cysts and pneumatoceles. ${ }^{2}$

Pneumothorax can also be induced iatrogenically, due to bronchoscopy, mechanical ventilation or in association with aerosolised pentamidine (a chemoprophylaxis), which predisposes to apical disease. ${ }^{1}$

\section{Learning points}

- There is a strong association between HIV infection and pneumothorax-they occur 450 times more frequently in AIDS patients versus the general population. ${ }^{1}$

- A pneumothorax in the context of HIV should trigger investigation and potential treatment for pneumocystis pneumonia. However, pneumothorax can develop subsequent to the diagnosis of pneumocystis pneumonia (PCP), and may be spontaneous or iatrogenic. There is also a high rate of recurrence, in up to one-third of patients, who may need subsequent pleurodesis or surgical repair.

- Common findings on CT in PCP include diffuse ground-glass opacity, pneumatoceles and cysts. $^{3}$

Contributors RGRL obtained the consent of the patient, wrote the article and submitted it for review. FA helped to select the best images and provided expert radiological opinion. She reviewed the final manuscript and gave advice. GH conceived the article and provided expert respiratory opinion. He reviewed the final manuscript and gave advice.

Competing interests None declared.

Patient consent Obtained. 


\section{Images in...}

Provenance and peer review Not commissioned; externally peer reviewed.

\section{REFERENCES}

1 Terzi E, Zarogoulidis K, Kougioumtzi I, et al. Human immunodeficiency virus infection and pneumothorax. J Thorac Dis 2014;6(Suppl 4):S377-82.
2 Eng RH, Bishburg E, Smith SM. Evidence for destruction of lung tissues during Pneumocystis carinii infection. Arch Intern Med 1987;147:746-9.

3 Kanne JP, Yandow DR, Meyer CA. Pneumocystis jiroveci pneumonia: high-resolution $\mathrm{CT}$ findings in patients with and without HIV infection. AJR Am J Roentgenol 2012;198:W555-61.

Copyright 2017 BMJ Publishing Group. All rights reserved. For permission to reuse any of this content visit

http://group.bmj.com/group/rights-licensing/permissions.

BMJ Case Report Fellows may re-use this article for personal use and teaching without any further permission.

Become a Fellow of BMJ Case Reports today and you can:

- Submit as many cases as you like

- Enjoy fast sympathetic peer review and rapid publication of accepted articles

- Access all the published articles

- Re-use any of the published material for personal use and teaching without further permission

For information on Institutional Fellowships contact consortiasales@bmjgroup.com

Visit casereports.bmj.com for more articles like this and to become a Fellow 